\title{
USING OUTLINING TECHNIQUE TO IMPROVE THE ABILITY OF THE STUDENTS OF THE ISLAMIC EDUCATION STUDY PROGRAM IN WRITING A RECOUNT TEXT
}

\author{
Amirudin Latif \\ Muhammadiyah University of Metro
}

\begin{abstract}
This study was intended to improve the ability of the students of the Islamic Education Study Program in writing a recount text by outlining technique. They were guided to write a recount text based on the outline they made before producing the text. The teaching and learning activities consisted of leading the students to make an outline, assigning them to make an outline, leading them write a recount text based on the outline, and the last assigning them to write a recount text based on the outline. The result showed that the students' ability in writing recount texts was improved. In the end of Cycle 2, there were 25 out 30 students who obtained score $>70$. Hence, the outlining technique is very helpful to improve the students' ability in writing recount texts.
\end{abstract}

Key words: Outlining technique, writing, recount text

English is one of the compulsory course taught in Islamic Education Study Program of Muhammadiyah University of Metro. The course is divided into four semesters which each of those is weighted two credits.

English course one which is given in semester one consists of twelve topics. Recount text is one of the topics given in this semester. The text is specially given in three meetings with writing as the targeted skill.

Writing is the most difficult skill. It should be a formal language, use various vocabularies, consider the audience who do not directly see the writer, and avoid redundancy (Brown (1994) cited in Weigle (2003: 15). Due to the difficult skill, writing must be taught using suitable technique based on the topic.

The fact that teaching writing was not properly done happened in English course one at Islamic Education Study Program of Muhammadiyah University of Metro. The lecturer taught writing recount text using conventional technique which made the students feel confused. The confusion made the students feel blank in starting to write a simple recount text, writing a recount text in correct sequence, and arranging the sentences into the readable text.

The students' difficulties in writing recount text gives the significant influence to their writing score obtained from a writing test administered after the teaching. Only seven out of thirty students got 70 in writing test. The result shows that the lecturer has failed to guide the students to write a recount text. The failure should not happen in the next writing class, so the lecturer applies a good technique to teach a recount text.

The researcher who is actually a lecturer of this class was interested in applying outlining technique as a solution for the students' problem in writing a recount text. This technique was chosen because it was considered useful to help students organize their writing. According to Gardner (2005:117), outlining is one of the most frequent techniques which writers use to discover ideas and the relationships among them. Dumais (1988:85) states that an outline helps the 
writer stick to the things he or she is going to write about. It helps the writer organize the sentences in such a way that his or her readers can easily understand what he or she is trying to get across to them. He also adds that an outline of a paragraph tells only what the writer really needs to write on and it uses as few words as possible.

Making an outline before writing is very useful. Nehiley (2010) mentions that using an outline allows the students to write rapidly and fluently. $\mathrm{He}$ also adds that an outline can improve the quality of the writing by providing a skeleton of the writing, serving as a road map, stimulating new ideas, and insuring the unity of topic.

There are two previous studies related to this study. First, Jusuf (2004) studied the use of outlining in teaching narrative writing to the third year students of SLTP Negeri Limboto Gorontalo. He claims that the students' ability in writing is improved and the students also seem to be more motivated and engaged in the teaching and learning activities. Second, Suryadi (2006) studied the use of outlining to improve descriptive writing skill of the eighth year students of SMP Negeri 4 Malang. He says that the implementation of outlining strategy has successfully improved the students' descriptive writing.

This study also implemented outlining technique which was of course different from the previous studies above in terms of the setting and subjects of the study, the kind of text, and the teaching procedures using the technique. The researcher used the outlining technique because it was suitable with the problems encountered by the students in writing class. Due to the reason, the researcher was interested in conducting classroom action research using outlining technique to improve the ability of the students of Islamic Education Study Program in writing a recount text.

\section{Method}

The research design of this study is collaborative Classroom Action Research (CAR) because the researcher involves a lecturer as collaborator who helps him to conduct the research from planning, implementing, observing, and reflecting.

This study was conducted at Islamic Education Study Program of Muhammadiyah University of Metro. The study program is under Islamic Religion Faculty, one of the five faculties in Muhammadiyah University of Metro.

The subjects of this study were the students of the first semester who took English course one. They were chosen as the subject of the study because they had some problems in learning writing recount text which caused the bad result in writing test administered after the writing class. The students' difficulties in writing recount text comprised of getting ideas to write, starting to write, and developing ideas into readable text.

Dealing with the problems encountered by the students in writing recount text, consequently the implementation of outlining technique to overcome the problems was needed.

In conducting the research, the researcher should go through some steps such as doing preliminary study (reconnaissance), analyzing and identifying problems, planning, implementing the plan, observing, and reflecting.

Reconnaissance or preliminary study was done to find the problems of teaching and learning problems especially in teaching writing recount text in the school. The data obtained were from observing teaching activities in the classroom. Two problems were found in the teaching of writing recount. The students did not know how to begin to write and how to arrange sentences into a paragraph. The possible cause was that the 
teacher did not use suitable techniques in teaching writing.

In planning stage, the researcher prepared everything to conduct the research. First, he prepared research instruments which were used as tool to collect the research data such as writing test, observation sheet, and field notes. He used writing test to measure the students' ability in writing recount text, observation sheet to record the students' participation during the classroom teaching and learning, and field notes to record all the events in the classroom. Second, he prepared the teaching media such as pictures, handout, and worksheet. Third, he designed lesson plan which implemented outlining technique in the teaching procedure to guide the students in writing a recount text. Fourth, he designed scoring rubric to score the students' writing. The last, he determined criteria of success which required all of the students to be active in the classroom and got 70 in writing test.

In implementing stage, the researcher acted as a lecturer who implemented outlining technique and followed the procedures designed in the lesson plan. The teaching and learning activities include brainstorming by questioning, leading the students to make an outline, modeling how to write a recount text based on the outline, assigning the students to make an outline and write a recount text.

In observation stage, the researcher was helped by a collaborator who observed all the reaction occurred in the teaching and learning process. The collaborator recorded the data of the students' involvement using an observation sheet and field notes.

In reflection stage, the researcher helped by collaborator evaluated the students' progress in writing recount text by giving test. After the result of the test was obtained, the researcher could determine whether the research was successful or not.

\section{Results}

The ability of the students' writing recount text showed the significant improvement from preliminary study, Cycle 1 and Cycle 2.

The preliminary study which was conducted on November 82013 showed that the majority of the students were not able to write recount texts. Only seven out of thirty students were rather able to write the text in spite of making some mistakes.

Cycle 1 which was conducted on November 152013 showed that the ability of the students in writing recount text was improved but the research was not successful because the targeted criteria were not fulfilled. Besides, ten students were still confused to write recount text which influenced their writing score. Seeing this condition, the researcher revised his lesson plan to get the improvement in Cycle 2.

Cycle 2 which was conducted on November 222013 showed the ability of the students in writing recount texts was totally improved. The thirty students were able to write recount texts. They felt easy to write recount text by using an outline. Due to the total success, the research was stopped.

The students' writing score from preliminary study, Cycle 1 , and Cycle 2 showed the significant improvement. In preliminary study, only seven out of thirty achieved 70. In Cycle 1 the students who achieved > 70 increased from seven to twenty students. In Cycle 2 all of the thirty students could achieve > 70. The following table describes the improvement of the students' writing score from preliminary study, Cycle 1, and Cycle 2. 


\begin{tabular}{cccccccc}
\hline & Ranged & \multicolumn{2}{c}{ Preliminary study } & \multicolumn{2}{c}{ Cycle 1 } & \multicolumn{2}{c}{ Cycle 2 } \\
\cline { 3 - 7 } No. & Scores & $\begin{array}{c}\text { Number of } \\
\text { Students }\end{array}$ & $\%$ & $\begin{array}{c}\text { Number of } \\
\text { Students }\end{array}$ & $\%$ & $\begin{array}{c}\text { Number of } \\
\text { Students }\end{array}$ & $\%$ \\
\hline 1. & $50-59$ & 19 students & $63 \%$ & - & $0 \%$ & - & $0 \%$ \\
2. & $60-69$ & 4 students & $14 \%$ & 10 students & $34 \%$ & - & $0 \%$ \\
3. & $70-75$ & 7 students & $23 \%$ & 11 students & $36 \%$ & 16 students & $54 \%$ \\
4. & $76-80$ & - & $0 \%$ & 7 students & $24 \%$ & 11 students & $36 \%$ \\
5. & $81-90$ & - & $0 \%$ & 2 student & $6 \%$ & 3 students & $10 \%$ \\
6. & $91-100$ & - & - & $0 \%$ & - & $0 \%$ \\
& & & & & & & \\
\hline
\end{tabular}

\section{Discussion}

This section discusses the research findings of both cycle one and two which are compared with the findings of previous researchers: Jusuf (2004) and Suryadi (2006). The findings comprise of the result of the students' writing and the percentage of the students' participation during the writing process.

The result of the students' writing in present study shows the significant improvement from preliminary study, Cycle one, and Cycle two. In preliminary study, the number of the students who got $\geq 70$ was seven students (23\%). In Cycle one, the number of the students who got $\geq 70$ increased to twenty students $(66 \%)$. In Cycle two, the number of the students who got $\geq 70$ increased to thirty students (100\%).

The significant improvement in writing also happens in previous studies. In Jusuf 's study (2004), the result of the students' writing increased significantly from pretest, cycle one, cycle two, and cycle three. In pretest, the students who got $\geq 65$ was only student $(4.4 \%)$ with mean score 5.5 . In cycle one, the number of the students who got $\geq 65$ was increased to eight students (34.8\%) with mean score 6.32. In cycle two, the number of the students who got $\geq 65$ was increased to sixteen students $(69 \%)$ with mean score 6.73. In cycle three, the number of the students who got $\geq 65$ increased to twenty three students $(100 \%)$ with mean score 7.5. Meanwhile in
Suryadi's study, the result of students' writing also increased significantly. In pretest, the students' average score was 6.7. It was increased to 82 in cycle one and 85 in cycle two.

Meanwhile, the students' participation during the writing process shows the number of increase either in the present study or in previous studies. In present study, the percentage of the students' involvement in cycle one was $65 \%$ and it was increased to $83 \%$ in cycle two. In Jusuf's study (2004), the percentage of the students' participation in the writing process was $78 \%$ in cycle one. It was increased to $91 \%$ in cycle two and $100 \%$ in cycle three. In Suryadi's study (2006), the students were happy and actively involved in the writing process in both cycle one and two but he did not mention the percentage of the students who participated in the writing process in both two Cycles.

Based on the comparison of the findings in present study and previous studies, it is found that the outlining technique is very helpful to improve the students' ability in writing (recount text in present study) and increase the students' involvement in the writing process.

\section{Conclusion}

Based on the findings obtained in two Cycles, it can be concluded that outlining technique which improved the ability of the students' Islamic Education Study Program in writing a recount text 
followed some steps namely brainstorming by questioning, leading the students to make an outline, modeling how to write a recount text based on the outline, and assigning the students to make their outline as well as to write a recount text.

Additionally, the result of the data analysis shows that outlining technique is successful in improving the ability of the students of Islamic Education Study Program. The success is shown by the achievement obtained in both Cycle 1 and 2 . In Cycle 1, twenty students $(66 \%)$ achieve $>70$ in writing recount text. In Cycle 2, all the thirty students $(100 \%)$ achieve $>70$ in producing the text which make the researcher must stop his action because the targeted criteria is fulfilled.

\section{Suggestions}

In accordance with the findings of this study, some suggestions are addressed to English teachers or lecturers who encountered the same problems in the teaching of writing, the same characteristics of the students and schools and also to the future researchers.

English teachers or lecturers should apply outlining technique in the teaching of writing. The technique can make the students feel easy to generate their ideas to write. It is also helpful when the students want to develop their ideas into a meaningful text. If the students have no difficulty in the learning of writing, they will be happy with the course.

Future researchers can take the result of the research as good model. It is suggested that they adapt the implementation of outlining technique in this research. They should make some changes in terms of text, teaching media, and the steps of the teaching. Taking all the content of this research to their future research is strongly prohibited.
The students are suggested to make an outline before they produce a piece of writing. The outline can make them feel easy to write a paragraph. If they have no problem in the teaching and learning of writing, they will have no problem in writing test and finally get good scores in the writing test.

All the writers, both senior and junior writers, should make an outline before producing some pieces of writing such article, short story, comic, novel, etc. Making an outline before writing can avoid them to miss some important points in their writing production and delete some unimportant ones in their product.

\section{References}

Dumais, L.A.W. 1988. Writing in English Departemen Pendidikan dan Kebudayaan Direktorat Jendral Pendidikan Tinggi. Jakarta: P2LPTK.

Gardner, P.S. 2005. New Directions : Reading, Writing, and Critically Thinking $\left(2^{\text {nd }}\right) . \quad$ Cambridge: Cambridge University Press.

Jusuf, R. H. 2004. Teaching Narration Through Outlining to the Third Year Students of SLTP 1 Limboto Gorontalo. Unpublished Thesis: State University of Malang.

Nehiley, J.M. 1998. Outline that Make Writing Easy. (on line). (http : // www.okcareertech.org/cimc/titles /lifeskillscomm/resources/commUnit4/Flo writeoutline.pdf, accessed on March 27 ${ }^{\text {th }}$ 2010). 
Suryadi. 2006. Using Outlining Technique to Improve Descriptive Writing Skill of the Eighth Year Students of SMP Negeri 4 Malang. Unpublished Thesis: State University of Malang.
Weigle, S.C. 2003. Assessing Writing. Cambridge: Cambridge University Press. 